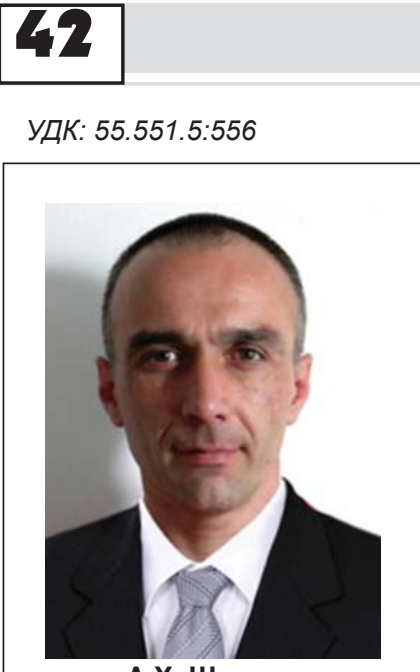

A.X. Шерхов

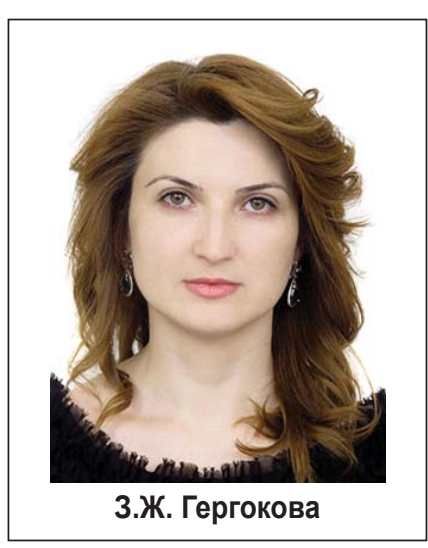

\title{
Assessment of the extent of possible damage by mudflows to the Verkhne-Chegemskoye rural settlement (Chegem River basin, Central Caucasus)
}

Abstract. The issues of ensuring the security of the territories of mountain settlements and infrastructure facilities, in the conditions of changes, as a result of climate warming, of the glacial situation in the upper reaches of mudflow rivers are considered. The results of the conducted research are presented, which show that mudflow risks and dangers in the current situation will not only remain relevant in the foreseeable future, but also, in all probability, will increase. Keywords: mudflow, outflow cone, high-altitude zone.

\section{ВВЕДЕНИЕ}

Потепление климата в последнее время несет значительные перемены в плане зарождения, развития и масштаба опасных склоновых и русловых процессов в высокогорной части северного склона Центрального Кавказа. С повышением границы нивальной зоны увеличиваются площади образования рыхлообломочного материала, возрастает количество осыпей, обвалов и оползней, способствующих появлению новых очагов селеобразования [1]. Обстановка усугубляется повышением частоты и интенсивности ливневых осадков в высокогорной зоне, а также опорожнением внутриледниковых полостей и озерных новообразований моренно-ледниковых комплексов.

Возникает необходимость внесения корректив в современное понимание вопросов обеспечения безопасности жизнедеятельности в горной и высокогорной зонах ввиду прогрессирующего увеличения факторов селевого риска. Определение участков селитебных территорий, находящихся под угрозой возможного негативного воздействия опасных склоновых и русловых процессов, является важным аспектом решения данной задачи.

\section{МАТЕРИАЛЫ И МЕТОДЫ}

Материалы, приведенные в настоящей статье, получены в ходе маршрутных обследований, проведенных сотрудниками ФГБУ «ВГИ» в июле 2020 г. по заказу администрация Чегемского муниципального района Кабардино-Балкарской Республики, с целью установления участков, подверженных природным опасностям, в том числе оползневым и селевым процессам, на территории сельского поселения Верхне-Чегемское. 
$\frac{\sqrt{2}}{3}$

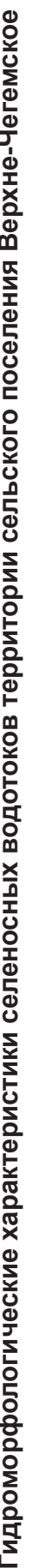

\begin{tabular}{|c|c|c|c|}
\hline 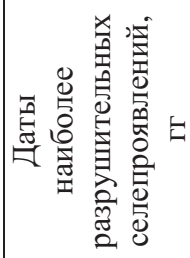 & 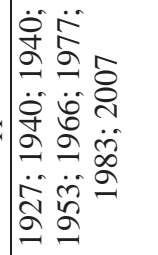 & 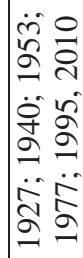 & 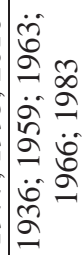 \\
\hline 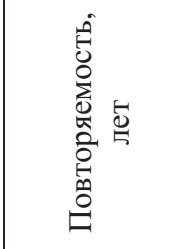 & $\frac{m}{r}$ & 0 & $\begin{array}{l}\tilde{c} \\
\tilde{c}\end{array}$ \\
\hline 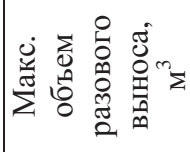 & \& & \& & 豙 \\
\hline 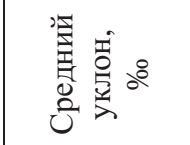 & $\stackrel{\cap}{n}$ & $\stackrel{尺}{\curvearrowright}$ & $\mathscr{0}$ \\
\hline 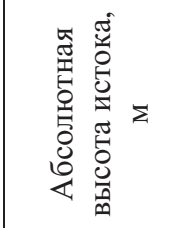 & $\begin{array}{l}\infty \\
m \\
m\end{array}$ & @) & $\begin{array}{l}\mathscr{B} \\
\stackrel{2}{n}\end{array}$ \\
\hline 䒿总 & $\stackrel{+}{\circ}$ & $\begin{array}{l}n \\
n\end{array}$ & $\cong$ \\
\hline 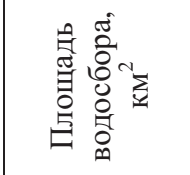 & 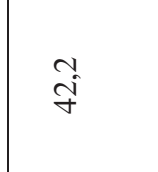 & $\stackrel{m}{\simeq}$ & ñ \\
\hline 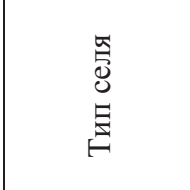 & 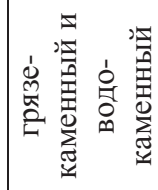 & 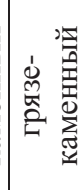 & 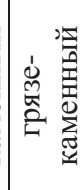 \\
\hline 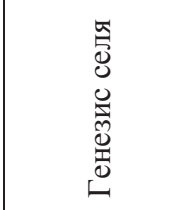 & 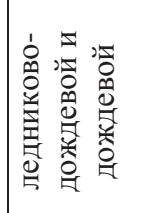 & 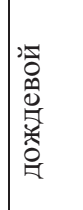 & 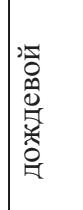 \\
\hline 芯 & 忿 & 总 & 突 \\
\hline
\end{tabular}

Определение зон возможного поражения проводилось на основе анализа предыдущих селепроявлений (архивные фото- и видеоматериалы, литературные источники, космоснимки) путем соотнесения расчетных критических объемов селевых выносов с высотными отметками рельефа транзитных участков на территории сельских поселений и с учетом морфометрических параметров русел водотоков, водо- и селепропускных сооружений и мостовых переходов.

\section{СЕЛЬСКОЕ ПОСЕЛЕНИЕ ВЕРХНЕ-ЧЕГЕМСКОЕ}

Территорию сельского поселения Верхне-Чегемское, выходя с прилегающих склонов правого борта Чегемского ущелья, пересекают русла селеносных рек Булунгусу, Сылыксу (с. Булунгу) и с левого борта ущелья река Джылгысу (с. Эльтюбю). Гидроморфологические характеристики указанных рек [2, 3] приведены в таблице 1.

P. Булунгусу. Правый приток р. Чегем - река Булунгусу берет начало от слияния двух рек ледникового происхождения - Кору и Ракыт - и протекает в верхней части с. Булунгу.

Анализ результатов проведенного обследования, с учетом морфометрических параметров местности и данных предыдущих селепроявлений, показывает, что селевые потоки, периодически сходящие по руслу р. Булунгусу, зачастую не вмещаются в природное русло реки и, выплескиваясь, заваливают часть территории селения, нанося значительный ущерб частным домовладениям. Площадь территории, заваливаемая селевыми выносами, $-0,063$ км² $^{2}$. Согласно расчетам, проведенным в соответствии с «Инструкцией по определению расчетных характеристик дождевых селей ВСН 03-76» [4], максимальный расход селя вероятностью превышения $1 \%$ обеспеченности для русла р. Булунгусу может достигать 499 м³/с. При таком развитии событий объем единовременного выноса может достигать 600000 $\mathrm{M}^{3}$, а площадь пораженной территории селения будет значительно увеличена, примерно до 0,12 км², соответственно ущерб, наносимый домовладениям сельчан, будет существенно выше, представляя опасность жизнедеятельности людей.

Ситуация усугубляется возможностью перекрытия р. Булунгусу оползневым массивом пород, расположенным на юго-западной окраине села, в вершине конуса выноса при выходе из ущелья и находящегося в нестабильном состоянии [5].

Сложность в оценке зон поражения по руслам рек, проходящим по территории сельских поселений, заключается в том, что образование затора по пути транзита селевого потока или перекрытие им подмостового сечения может сместить селевой поток в сторону. То есть, любая глыба поперечником до 3-4 м, которая остановится в русле, может перенаправить селевой поток так, что селевые массы будут выходить непосредственно на подворья жителей села. Таким образом, существует вероятность по- 


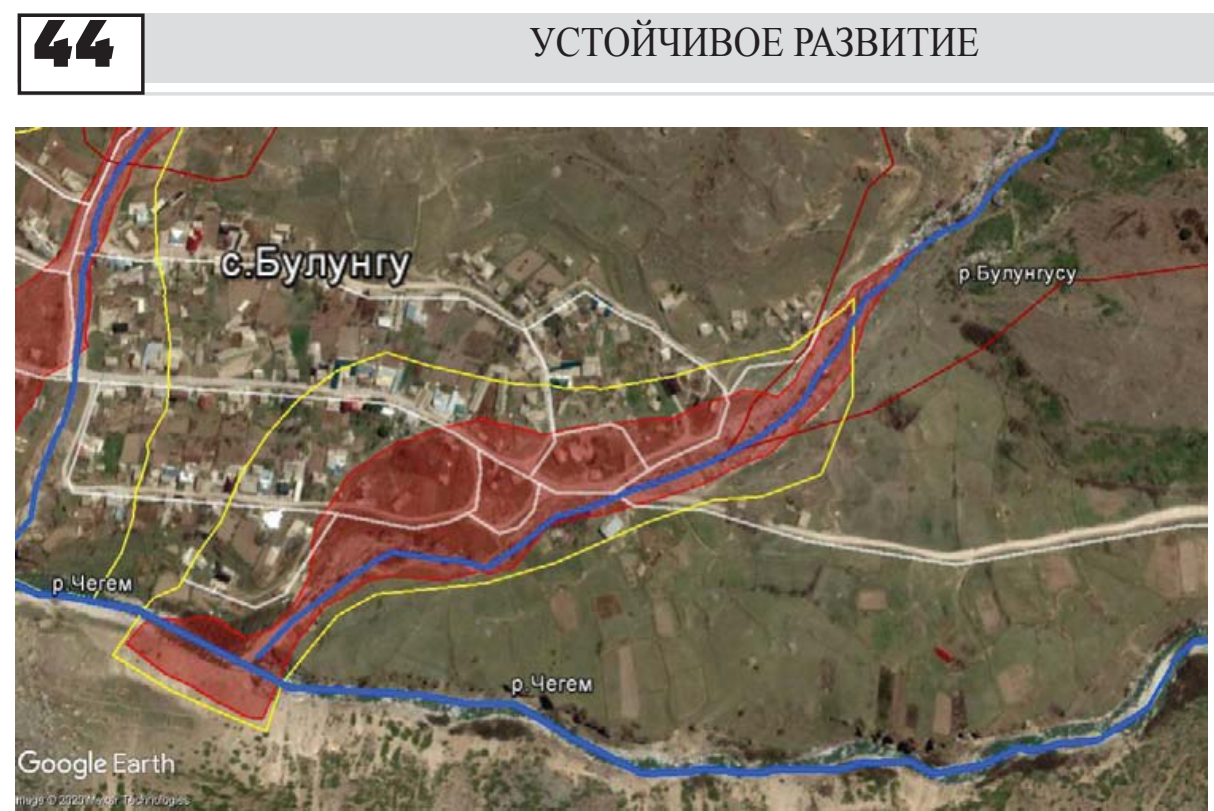

Puc. 1. Схема расположения зон поражения н. п. Булунгу селями р. Булунгусу:

красным цветом выделена актуальная зона поражения, желтым зона возможного поражения. Космоснимок Google Earth.

ражения селем практически любого участка конуса выноса.

На прилагаемых рисунках красным цветом обозначены участки территории села, подвергавшиеся негативному воздействию селепроявлений в прошедшие годы и признанные опасными для жизнедеятельности. Желтым контуром обозначены зоны потенциальной опасности, определяемые с учетом приведенных критических расчетных параметров селевых потоков для каждого русла - т. е. зоны возможного поражения. Последние, в свою очередь, можно считать лишь приблизительными в силу многофракторности явления и с учетом рисков мгновенного изменения текущей обстановки в момент прохождения селевого потока по данным руслам.

В зонах поражения и возможного поражения селевыми потоками по правую сторону р. Булунгусу на территории села Булунгу (рис. 1) находится несколько десятков частных домовладений, приусадебных участков, жилых и нежилых построек, расположенных по улицам Мизиева, Кулиева, Гемуева и пер. Кюнлюм.

P. Сылыксу. Река Сылыксу является правым притоком р. Чегем и протекает в срединной части с. Булунгу.

Анализ результатов проведенного обследования, с учетом морфометрических параметров местности и данных предыдущих селепроявлений, показывает, что селевые потоки, регулярно сходящие по руслу р. Сылыксу, периодически заваливают часть территории селения, нанося значительный ущерб частным домовладениям. Площадь территории, заваливаемая селевыми выносами, - 0,015 км². Согласно расчетам, проведенным по «Инструкции по определению расчетных характеристик дождевых селей ВСН 03-76» [4], максимальный расход селя вероятностью превышения 1 \% обеспеченности для русла р. Сылыксу может достигать 263 м³/с.

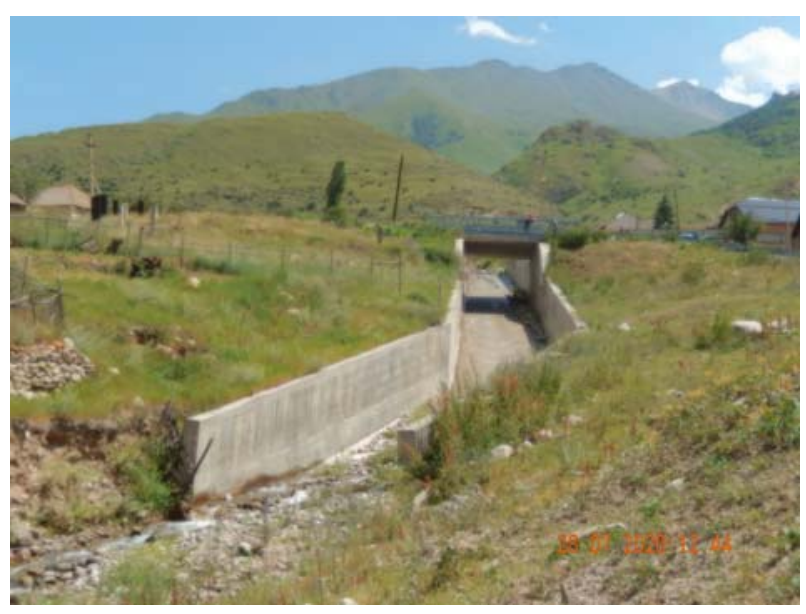

Puc. 2. Селепропускной лоток в русле р. Сылыксу

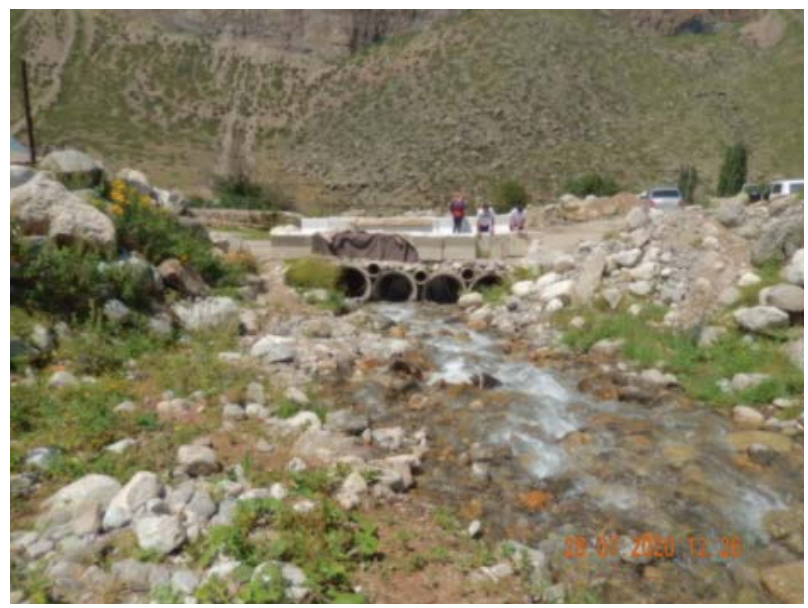

Puc. 3. Трубный переход в русле р. Сылыксу, расположенный выше селепропускного лотка, на территории с. Булунгу 


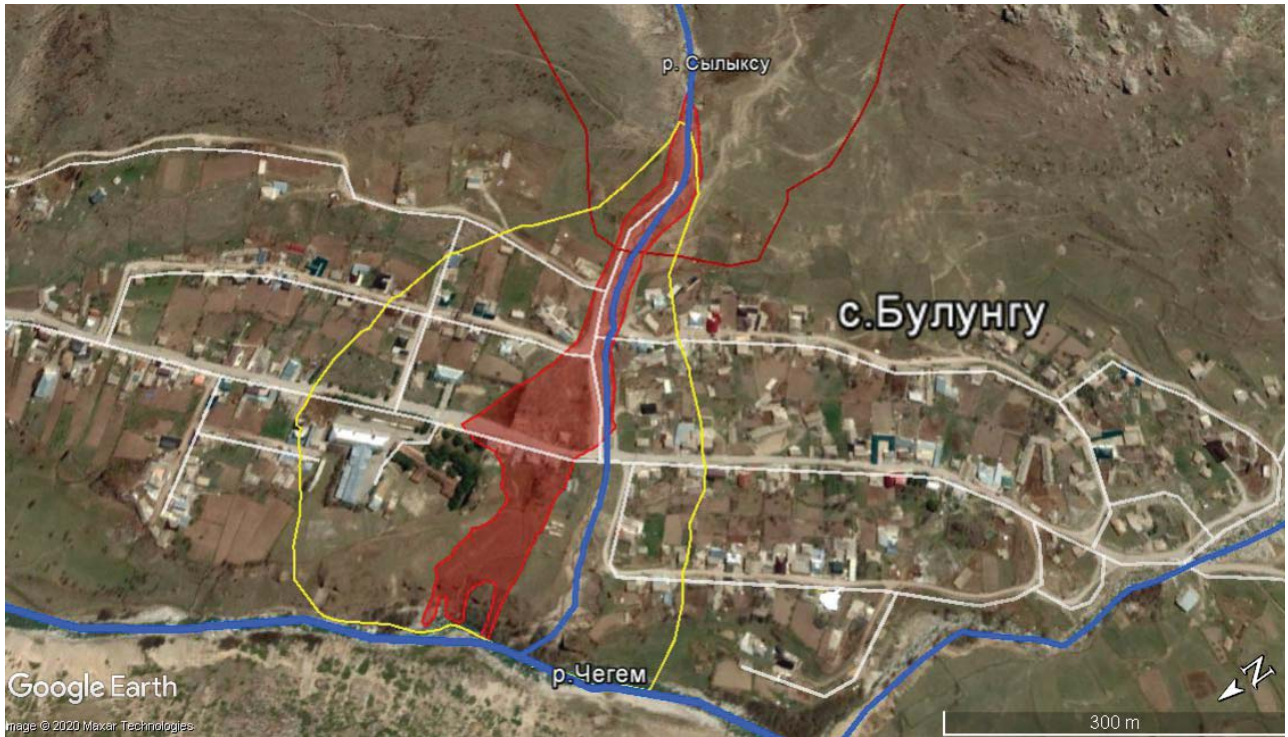

Puc. 4. Схема расположения зон поражения с. Булунгу селями р. Сылыксу: красным цветом выделена актуальная зона поражения, желтым зона возможного поражения. Космоснимок Google Earth

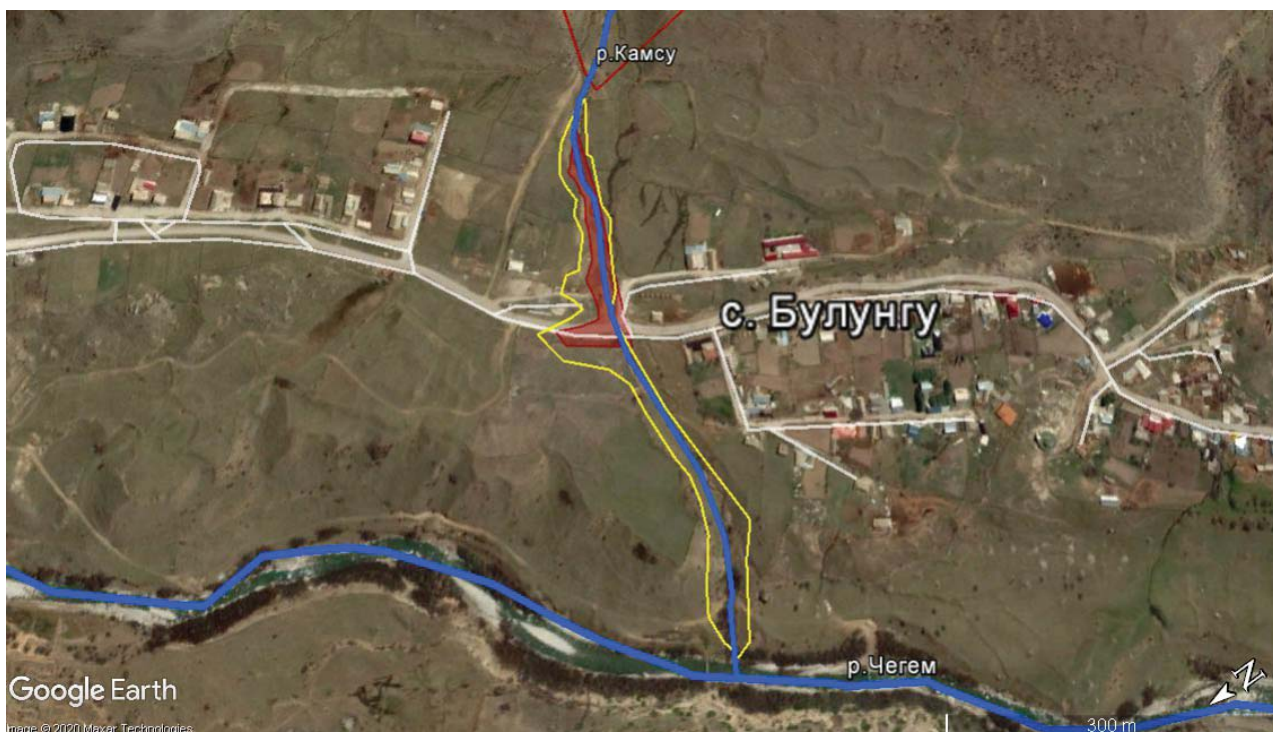

Puc. 5. Схема расположения зон поражения с. Булунгу селями р. Камсу: красным цветом выделена актуальная зона поражения, желтым - массы р. Сылыксу. Так, площадь поперечного сечения лотка составляет порядка 17 м² $^{2}$ а площадь сечения расчетных максимальных расходов селе-

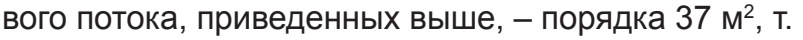
е. превысит реальную более, чем в два раза. При этом еще до лотка селевой поток может выйти или в левую, или в правую сторону и оказать разрушительное воздействие на строения и участки с. Булунгу.

Трубный переход под автодорогой, пересекающей реку выше селевого лотка (рис. 3), явно не способен пропустить устьевые расходы селевых потоков. В случае затора в нем, с учетом малого перепада высот уровня домов и русла реки, селевые массы неизбежно выплеснутся на территорию

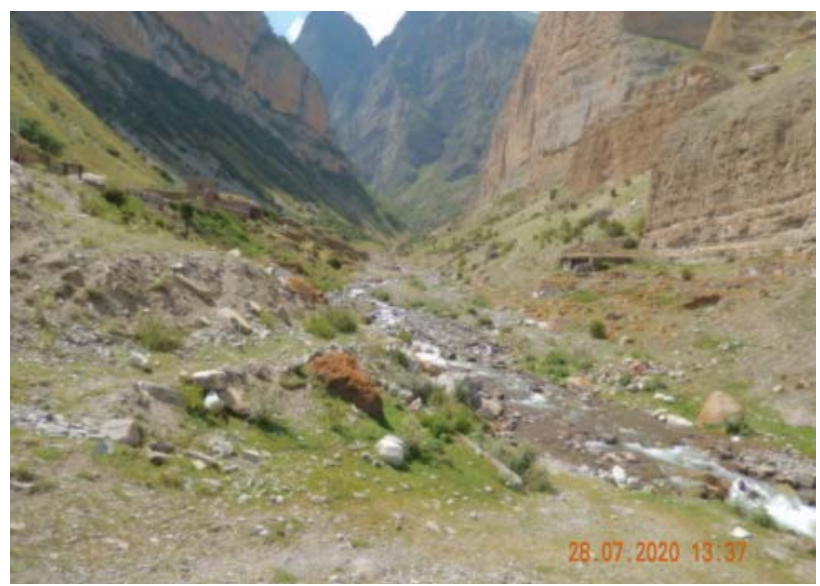

Puc. 6. Русло реки Джылгысу на выходе из ущелья прилегающих домовладений.

В зонах поражения и возможного поражения селевыми потоками по правую и левую стороны р. Сылыксу на территории села Булунгу также находится несколько десятков частных домовладений, приусадебных участков, жилых и нежилых построек, расположенных по улицам Мизиева, Кулиева, Гемуева и пер. Ачы, Думала и Эльтюбинский (рис. 4).

Помимо селеносных рр. Булунгусу и Сылыксу на северовосточной окраине села через трубу под автодорогой в р. Чегем впадает р. Камсу. Она также несет в паводок грязекаменный материал, который периодически забивает водопропускное отверстие. Жилых построек в настоящее время вблизи нет, но инфраструктурные сети и полотно автодороги могут подвергаться разрушению (puc. 5).

P. Джылаысу. Река Джылгысу является левым притоком$$
\text { вые массы неизбежно выплеснутся на территорию }
$$ 


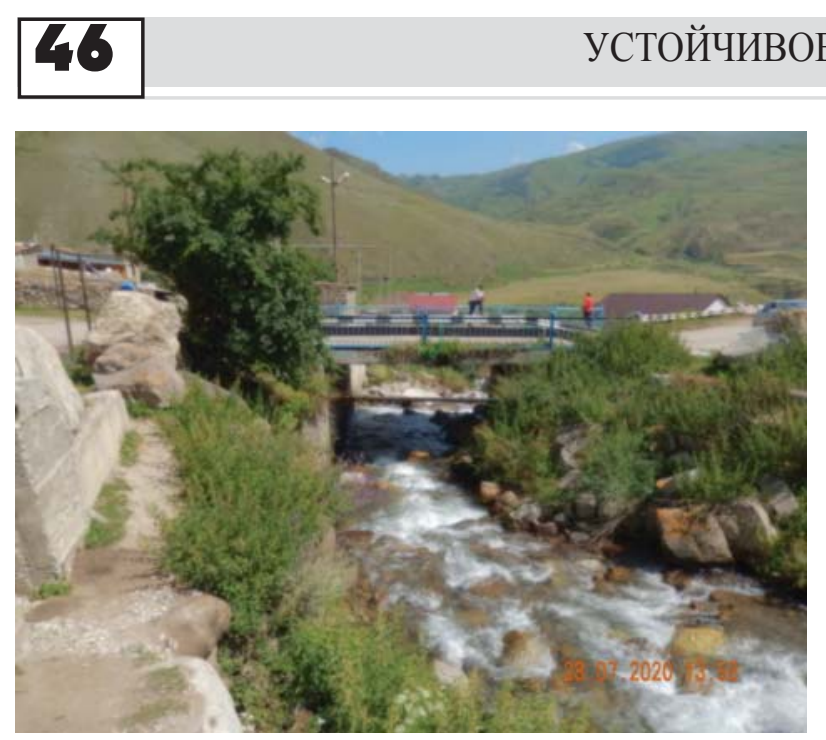

Puc. 7. Мостовой переход в русле реки Джылгысу на территории с. Эльтюбю

р. Чегем, берет начало в урочище и протекает через с. Эльтюбю.

Анализ результатов проведенного обследования, с учетом морфометрических параметров местности и данных предыдущих селепроявлений, показывает, что следы схода наносоводных и селевых потоков не выходят за границы естественного русла. Coгласно расчетам, проведенным по «Инструкции по определению расчетных характеристик дождевых селей $\mathrm{BCH}$ 03-76» [4], максимальный расход селя вероятностью превышения 1 \% обеспеченности для русла р. Джылгысу может достигать 586 м³/с, а объем единовременного выноса 700000 м³. Современное состояние транзитного руслового тракта, с учетом текущей обстановки, а также ввиду значительных ширины и высоты перепада русла реки с линией расположения строений на территории села, представляется удовлетворительным. Однако

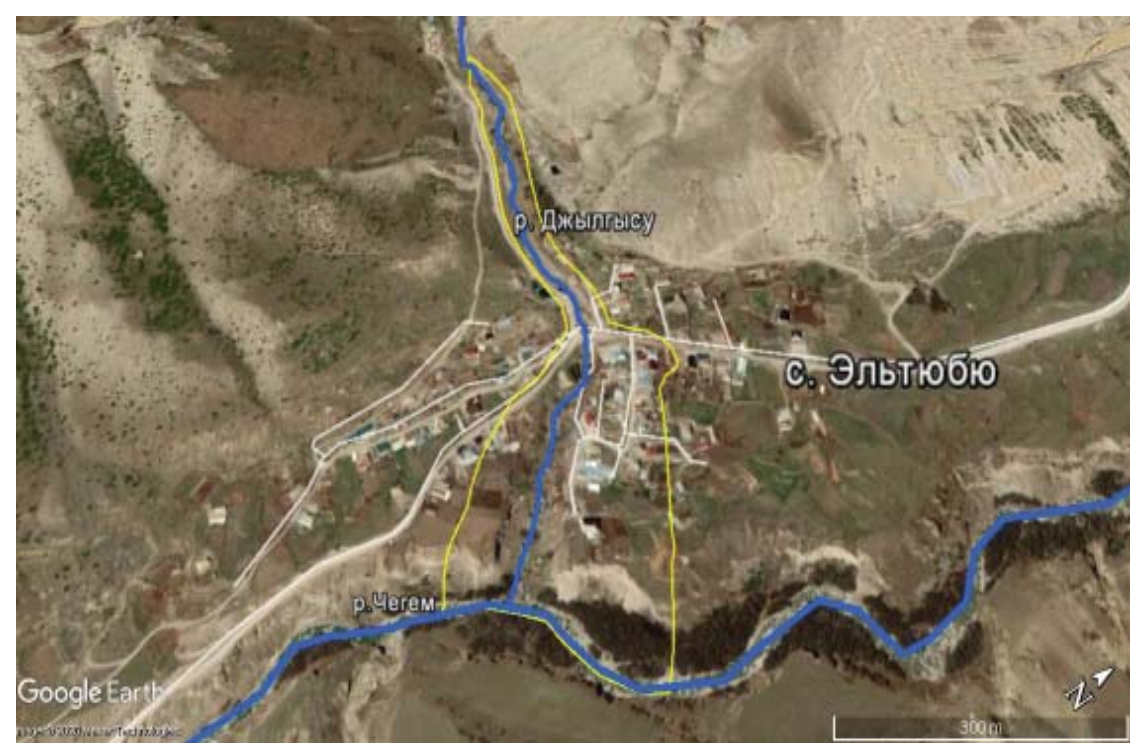

Puc. 9. Схема расположения зоны возможного поражения с. Эльтюбю селями р. Джылгысу:

красным цветом выделена актуальная зона поражения, желтым зона возможного поражения. Космоснимок Google Earth

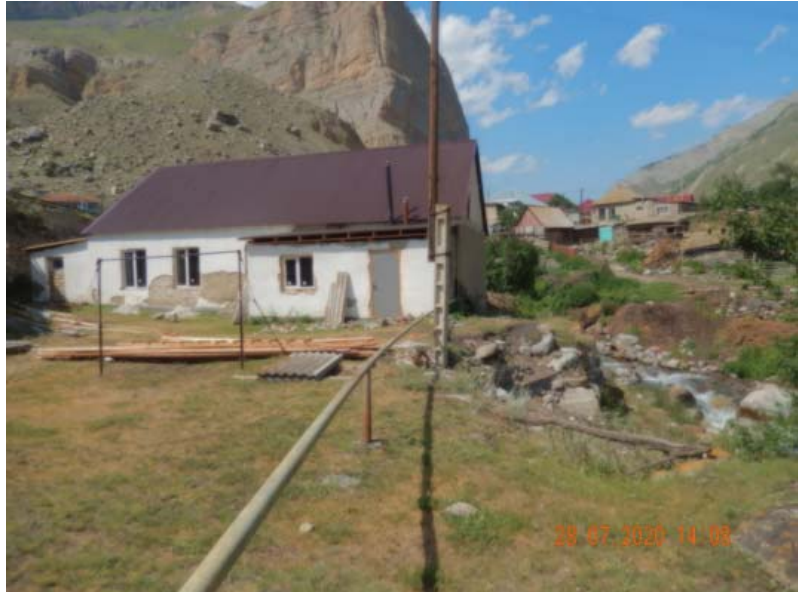

Puc. 8. Жилые и нежилые постройки

с. Эльтюбю на береговых уступах,

выдающихся в русло реки Джылгысу

могут вызывать опасения места пересечения реки магистралями жизнеобеспечения (газ, водопровод), а также зона прохождения реки под мостовым переходом в центре села. При сходе селевых потоков с правых притоков р. Джылгысу, по всей вероятности, будет вовлечено большое количество деревьев, которые неизбежно образуют затор на участке мостового перехода. Так, площадь поперечного сечения проема русла под мостом составляет порядка 20 м², а площадь пропускного сечения расчетных максимальных расходов, приведенных выше, порядка 100 $\mathrm{M}^{2}$, т. е. превысит реальную более чем в пять раз. В случае перекрытия проема моста селевые массы могут выйти на территорию частных домовладений, расположенных слева и ниже мостового перехода. Непосредственно за переходом на береговых уступах, выдающихся в русло реки, расположены жилые и нежилые постройки, которые также могут быть подвержены негативному влиянию масштабных селепроявлений. Могут пострадать дома и подворья, расположенные по улицам Шахмурзаева, Кулиева и пер. Жылгы (рис. 6-9).

\section{ЗАКЛЮЧЕНИЕ}

Результаты проведенных обследований, с учетом морфометрических данных местности, анализа следов предыдущих селепроявлений, а также расчетов критических значений основных параметров селевых потоков по рассматриваемым руслам, подтверждают наличие зон, подверженных негативному воздействию селевых процессов на территории указанных населенных пунктов. 
В связи с изменяющейся, в результате потепления климата, гляциальной обстановкой в верховьях рек Булунгусу и Сылыксу, протекающих по территории села Булунгу, сельского поселения Верхне-Чегемское, селевые риски в данном районе не только останутся актуальными в обозримом будущем, но и, по всей вероятности, возрастут. Согласно обследованиям, проводившимся ранее Э.В. Запорожченко и др., основные составляющие р. Булунгусу - рр. Ракыт и Кору в связи с изменяющейся в результате потепления климата гляциальной обстановкой в верховьях становятся крайне селеопасными. При том, что характер процессов, ведущих к возникновению условий для развития водного потока по селевому сценарию по этим руслам различен, угроза срабатывания очагов в их верховьях остается высокой [6].

Сохраняется потенциальная опасность селепроявлений в русле реки Джылгысу, протекающей по территории села Эльтюбю, ввиду наличия в верховьях реки массивов с большим количеством погребенных льдов. Таким образом, состояние и современное положение транзитных русловых трактов на территории сел может оказаться неадекватным реальной селевой энергетике. Это следует учитывать при определении зон, находящихся под угрозой возможного поражения.

\section{ЛИТЕРАТУРА}

1. Докукин М.Д. и др. О селях 2011 года на Северном склоне Центрального Кавказа // Геориск, 2012. № 7. С. 30-40.

2. Кондратьева Н.В. и др. Кадастр селевой опасности Юга Европейской части России. - М.-Н.: «Феория», 2015. $148 \mathrm{c.}$

3. Кадастр лавинно-селевой опасности Кабардино-Балкарской Республики. Под общей редакцией Залиханова М.Ч. Разумов В.В., Кюль Е.В. и др. - С-Пб.: Гидрометеоиздат. 2001. 54 C.

4. Инструкции по определению расчетных характеристик дождевых селей ВСН 03-76. - Ленинград: Гидрометеоизdam, 1972. C. 28.

5. Результаты наземного обследования рр. Ц. Ракыт и Кору 16 - 20.08.2010 е. Докладная по результатам обследования ОАО «Севкавгипроводхоз» от 23.08.2010 г., исх. № 01/2386 om 28.09. 2010 г.

6. Запорожченко э.В. и др. Селевые процессы на современном этапе деградации горного оледенения // Вестник ВНЦ, 2009. Том 9, № 1. С. 44-49.

\section{REFERENCES}

1. Dokukin M. D. et al. About the 2011 mudslides on the Northern slope of the Central Caucasus. Georisk, 2012. No. 7. pp. 30-40.

2. Kondratieva N. V. et al. Cadastre of mudflow hazard in the South of the European part of Russia. M-N «Feoria». 2015. $148 \mathrm{~s}$.

3. Cadastre of avalanche and mudflow hazard of the Kabardino-Balkar Republic. Under the general editorship of Zalikhanov M. Ch.; Razumov V. V., Kuhl E. V., and others. St. Petersburg: Hydrometeoizdat. 2001. 54 p.

4. «Instructions for determining the design characteristics of rainstorms VSN 03-76». Hydrometeoizdat. Leningrad. 1972. p. 28.

5. Results of the ground survey of the rr. Ts. Rakyt and Koru 16-20.08.2010 Report on the results of the survey of JSC «Sevkavgiprovodkhoz» dated 23.08.2010, ex. No. 01/2386 of 28.09. 2010

6. Zaporozhchenko E. V. et al. Mudflow processes at the present stage of mountain glaciation degradation. Bulletin of the VNC, 2009. volume 9, No. 1. pp. 44-49.

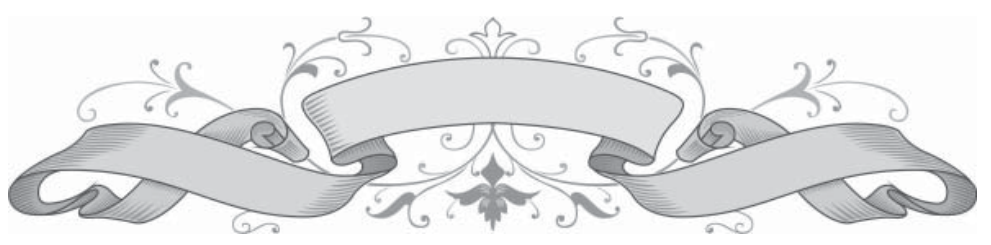

